\title{
TEOLOGICZNE KONOTACJE PHYSIS W ODNIESIENIU DO SWIATA STWORZONEGO W MOWACH GRZEGORZA Z NAZJANZU
}

Analizując twórczość Grzegorza z Nazjanzu, zauważa się, że jego refleksja teologiczna osadzona jest w bardzo charakterystycznym dla Wschodu nurcie rozważań o ekonomii zbawczej ${ }^{1}$. Punktem ich wyjścia jest zasadnicza prawda o tym, że wszystko ma początek w Bogu. Toteż bardzo często Grzegorz odwołuje się do faktu stworzenia przez Boga całego kosmosu. Zachęca, by najpierw szukać w otaczającym świecie praw i porządku, jakie zawarł w nim Stwórca, a następnie przejść do zagadnień dotyczących zbawienia, zwłaszcza celu Wcielenia. W swoim wykładzie Kapadocczyk posługuje się różnorodnymi terminami i sformułowaniami. Jednak w niniejszym artykule uwaga zostanie skoncentrowana głównie na tych jego wypowiedziach, w których pojawia się słowo фúøıs.

Idea rozpatrywania zbawczego działania Boga w kontekście dzieła stworzenia pojawia się u nauczyciela z Nazjanzu bardzo wcześnie. Już w czwartym roku posługiwania kapłańskiego (364 r.) podziwia on harmonię i piękno świata, by w ten sposób pobudzić wyobraźnię słuchaczy. Zwraca się do nich słowami:

\begin{abstract}
„Uczmy się praw stworzenia, mianowicie że niebo, ziemia, morze i cały ten świat

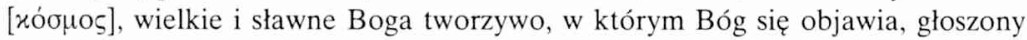
nawet poprzez milczenie, dopóki ustala się w sobie i żyje w pokoju mieszcząc się

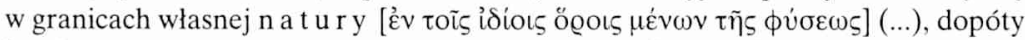
jest harmonijnym światem, zgodnie ze swą nazwą [kosmos], i pięknością niedostępną, nad którą niczego nikt nigdy nie potrafi wymyślić wznioślejszego i wspanialszego"2.
\end{abstract}

Celowo przytoczony tu został nieco dłuższy fragment opisu piękna i harmonii otaczającego świata, co w zamiarze Grzegorza miało uzmysłowić słuchającym -

${ }^{1}$ Por. E. Osborn, Theology and Economy in Gregory the Theologian, w: H.C. Brennecke E.L. Grasmück - C. Markschies (red.), Logos. Festschrift für Luise Abramowski zum 8. Juli 1993, Berlin - New York 1993, 361-383.

2 Oratio 6, 14, SCh 405, 158, w. 12, Mowy wybrane (dalej: Mowy), thum. zbiorowe, Warszawa $1967,142$. 
jak na to wskazuje dalszy kontekst tej wypowiedzi - potrzebę pokoju w człowieku i między ludźmi. Przy okazji Grzegorz porusza tu bardzo istotną kwestię teologiczną, a mianowicie, że świat to „wielkie i sławne Boga tworzywo, w którym Bóg się objawia". Jest to zasadnicza teza, którą Grzegorz podkreślał niezwykle często w swoim nauczaniu. Zatem świat materialny jest boski, ponieważ od Boga pochodzi i jest miejscem, w którym Bóg się objawia; dla Grzegorza ma więc wymiar teologiczny.

W opisywaniu takiego właśnie świata Grzegorz posługuje się różnymi terminami, wśród których często pojawia się też słowo фúoıs: poświadcza to także powyższa wypowiedź. W przekładzie na język polski dosłowne jej brzmienie powinno być jednak następujące: ,mieszcząc się we własnych granicach natury”. Sformułowanie „własne granice” wskazuje na ograniczoność świata oraz jego skończoność w przeciwieństwie do nieskończonego Boga, przy czym

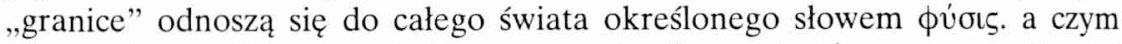

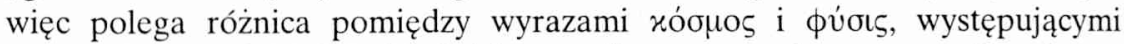
w powyższym tekście? Dokładniejsza analiza zawartych w nim myśli wykazuje, że używając wyrazu xóouo Kapadocczyk akcentował istnienie świata, natomiast w фúoıৎ zawarł sposób jego bytowania, gdyż „ustala się w sobie i żyje w pokoju". W tych słowach kryje się także piękno, harmonia i doskonałość omawianego świata, czyli cechy wskazujące na jakość tego bytu i rzeczy do niego przynależące.

Do aktu stworzenia Grzegorz powracał w swym nauczaniu wielokrotnie. W jednej z mów zastanawiał się nad obfitością darów życia, jakie Stwórca dał stworzeniom na lądzie, w powietrzu i w wodzie, a co według niego było przejawem bogactwa dobroci Boga. Ujawniło się ono dlatego, gdyż Bóg „,chciał

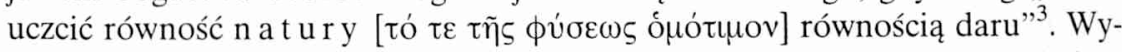
stępujące w refleksji Grzegorza słowa: „,bogactwo”, „dobroć”, „dar”, świadczą bezsprzecznie o pozytywnej wizji świata, a zwłaszcza o harmonijnej relacji między Bogiem a jego dziełem. Autor tych myśli pragnie, aby w ten właśnie sposób postrzegany był przez każdego człowieka otaczający świat, w którym z kolei dostrzegalna jest równość darowanych, a więc udzielanych czy przekazywanych przez Boga, wszelkich „elementów” składających się na obfitość życia w świecie. To właśnie stanowi o wspomnianej przez Grzegorza równości tego, co zostało określone słowem фúoıs. Odnosi się ono zatem do świata zaistniałego dzięki interwencji Boga i posiadającego piękność kształtu i harmonii.

Również przy innej okazji swego pasterskiego nauczania biskup Konstantynopola bardzo dobitnie wypowiadał się o pochodzeniu świata od Boga. Rzeczy Mu dawane czy ofiarowane należy traktować ,,jako od początku do

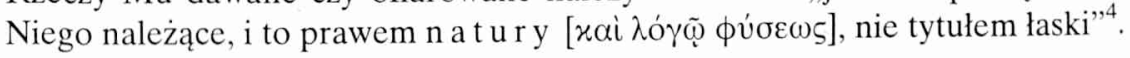

${ }^{3}$ Oratio 14, 25, PG 35, 889C, Mowy, s. 179. 


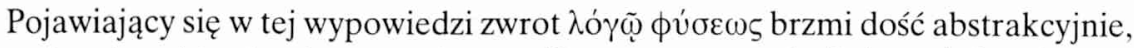
mając charakter języka prawniczego. Tymczasem w relacji do wyżej podanych eksplikacji zwrot ten nabiera konkretnego odniesienia. Skoro bowiem Bóg zrodził świat rzeczy materialnych, to są one Jego rzeczywistym przedłużeniem, tak jak zrodzony potomek jest przedłużeniem gatunkowym rodziców.

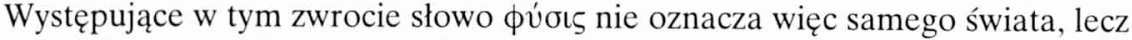
wskazuje na źródło jego pochodzenia. Wszystkie zatem rzeczy materialne należą do Boga ze względu na prawo własności i ich pochodzenie.

Nazjanzeńczyk, zachwycając się otaczającą przyrodą, rozmaitością roślin i niezwykłą ich pięknością, w taki sposób zwraca się do swego słuchacza:

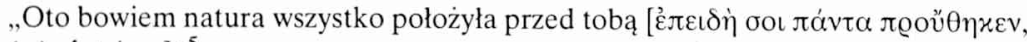
(...), $\dot{\eta} \phi \dot{\sigma} \sigma \iota \zeta] ” 5$.

Nie ulega wątpliwości, że słowo фúøı nabiera tu nowej, niespotykanej dotąd funkcji. Będąc w tym zdaniu podmiotem wyróżnia się swoistym działaniem, ujawniając się jednocześnie jako upersonifikowana moc, która „wszystko położyła”. Dodatkowym elementem, który ją wzmacnia, jest rodzajnik $\dot{\eta}$ i związek z czasownikiem, dzięki któremu púøıs uzyskuje funkcję rządzącą, stając się terminem dynamicznym. Czy jest to moc przypadkowa czy też otrzymana? Ma się przeświadczenie, że Grzegorz pragnie uświadomić słuchaczowi, by - jak dalej stwierdza - ,po tych przynajmniej dobrodziejstwach poznać Boga"6. Фúøıৎ oznacza tu zatem całą rzeczywistość materialną, której kształt i wygląd nie jest dziełem przypadku, ale ,najwidoczniejszym świadectwem potęgi Bożego tworzenia"?

Na dynamiczną moc słowa фúøıৎ wskazuje też inne stwierdzenie Kapadocczyka, w którym wzywa, by pójść ,za prawem i porządkiem n a t u r y [vó $\mu \omega$ xai

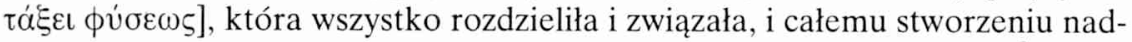
ała postać jednego świata [xó $\mu$ ov éva], złożonego z wielu żywiołów" ". Rów-

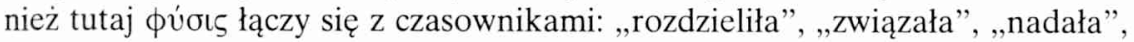
dzięki którym staje się upersonifikowaną mocą. Bardzo charakterystycze w tej

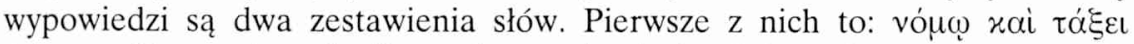

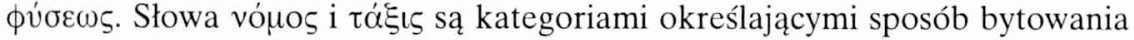

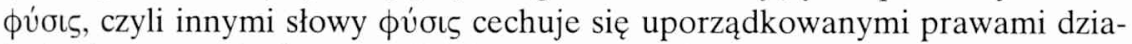
łania, jest uosobieniem wszelkiej prawidłowości. Grzegorz nie komentuje dokładnie tej myśli, nie podpowiada, skąd pochodzi w фúoıৎ ta uporządkowana prawidłowość. Jednak z wyżej już zanalizowanych cytatów z jego twórczości wynika, że została ona dana przez Stwórcę. Dlatego Grzegorz zaleca słuchają-

\footnotetext{
${ }^{4}$ Oratio 30, 9, SCh 250, 242, w. 6, Mowy, s. 333.

5 Oratio 28, 26, SCh 250, 156, w. 11, Mowy, s. 305.

${ }^{6}$ Oratio 28, 26, SCh 250, 156, w. 12, Mowy, s. 305.

7 Oratio 28, 26, SCh 250, 158, w. 37-38, Mowy, s. 306.

${ }^{8}$ Oratio 4, 120, SCh 309, 286, w. 7, Mowy, s. 111.
} 
cym, by kroczyli tymi uporządkowanymi prawami, gdyż są dobre. Drugie

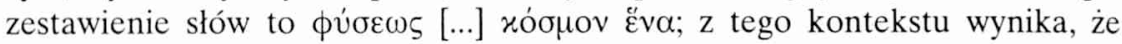

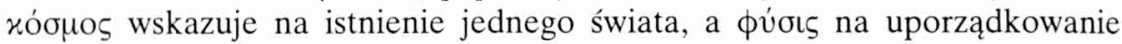
w tym świecie całego stworzenia, czyli na to, co zawierają m.in. zawarte w powyższej wypowiedzi czasowniki „rozdzieliła”, „związała”, „nadała”.

Swoistym uzupełnieniem interpretacji powyższej wypowiedzi są słowa, mające tylko pozornie sprzeczną treść w zestawieniu $z$ dokonanymi wcześniej analizami. Kapadocczyk informuje w nich „o zwierzętach dziwnych i złożo-

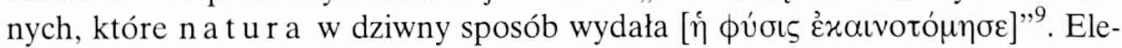
mentem, który łączy się merytorycznie z powyższą analizą, jest pojawienie się w tej wypowiedzi i $\dot{\eta} \phi \dot{\sigma o s}$, co oznacza, że wymienione słowo charakteryzuje się mocą dynamiczną, którą w sobie zawiera. Poprzedzone rodzajnikiem $\eta$ i połączone z czasownikiem éxaıvotó

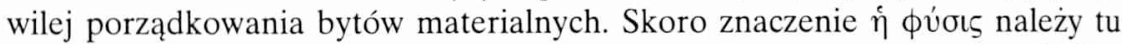
postrzegać jako twórcze, porządkujące działanie, którego owocem jest doskonałość i piękno kształtów, dlaczego więc to słowo zostało użyte dla opisu dziwnych i złożonych zwierząt. Swego rodzaju „usprawiedliwieniem” dla autora

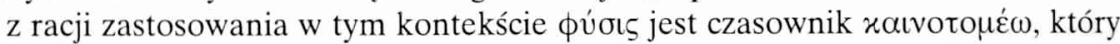
oznacza: „ustanawiać na nowo”, „wprowadzać zmiany”. Toteż polski przekład w sposób właściwy oddaje tę okoliczność słowami „w dziwny sposób”. Niezależ-

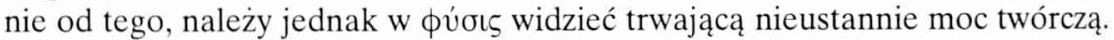

Znamienne dla niniejszych rozważań są słowa wyżej już cytowane, opisujące upersonifikowaną moc udzielającą całemu stworzeniu postać jednego świata, który złożony jest $\mathrm{z}$ wielu żywiołów. Jednym $\mathrm{z}$ nich to stworzenia żyjące. Grzegorz, zachwycając się nad nimi, stwierdza, że „stanowią one prze-

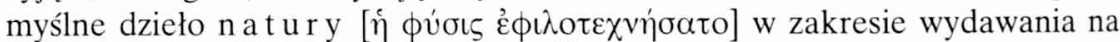
świat stworzeń obdarzonych życiem" ${ }^{\prime 10}$. Zachodzi tu taka sama, jak wyżej, sytuacja kontekstualna, kiedy z czasownikiem, zyskując w ten sposób znaczenie działającej mocy, która ukierunkowana jest na utrzymywanie porządku w odniesieniu do stworzeń obdarzonych życiem. Fakt tego uporządkowania jeszcze bardziej podkreśla użyty

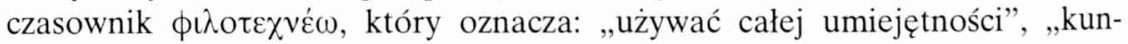
sztownie ułożyć". Bez wątpienia trzeba uznać, że Grzegorz w tym stwierdzeniu pragnie wyrazić nie tylko swój podziw, ale także swoje uwielbienie dla potęgi Bożego tworzenia, które zostało ukryte w świecie materii. Dla podkreślenia tych wszystkich aspektów słowo фúøıৎ nadaje się najbardziej.

Kontynuując refleksje nad przedziwnym światem stworzeń żywych, mówca

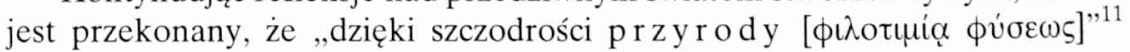

\footnotetext{
${ }^{9}$ Oratio 5, 24 , SCh 309, 338, w. 12, Mowy, s. 124.

${ }_{10}$ Oratio 31,10 , SCh 250, 294, w. 16, Mowy, s. 350.

11 Oratio 31, 31, SCh 250, 294, w. 23, Mowy, s. 350.
} 
ludzie mogą podziwiać tak rozmaite zjawiska u zwierząt. W tym zwrocie słowo фúoıs oznacza całość stworzonego świata, który charakteryzuje się wewnętrzną spójnością i uporządkowaniem. Tak pojęty świat, jak już wyżej wykazano, obdarzony został kreatywną siłą, czego wyrazem jest niezwykła różnorodność

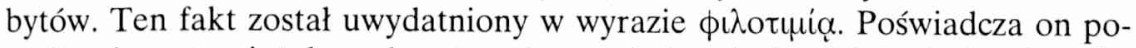
nadto pierwotną i stałą cechę otaczającego świata, który dzięki tkwiącej w nim mocy jest zdolny sam z siebie kształtować i porządkować swe oblicze. Ten element zawiera się właśnie w słowie фúoıs.

Przedstawiony wyżej porządek, będący cechą konstytutywną otaczającej rzeczywistości, która z racji tego uporządkowania nazywana jest фúøıৎ, można dostrzec także w innych miejscach nauczania pasterskiego Grzegorza. Oto fragment jego komentarza:

„Jaka to zaleta dla ognia, że pali? Właściwości palenia udzieliła mu n a t u r a [tò

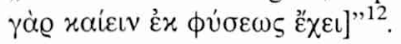

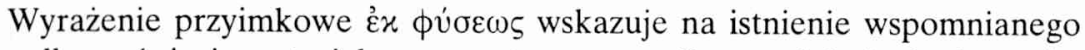
porządku w świecie materialnym, a w tym przypadku w odniesieniu do ognia, którego właściwością jest palenie. Tym zwrotem zostało więc wyrażone deterministyczne prawo tego zjawiska, które jest niezmienne. W dosłownym przekładzie na język polski zwrot ten informuje czytelnika, że tę właściwość ogień „ma z natury” lub „ma od natury”. Takie thumaczenie wskazuje także na

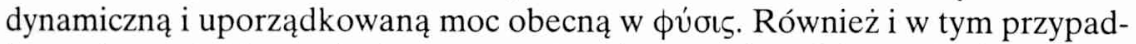

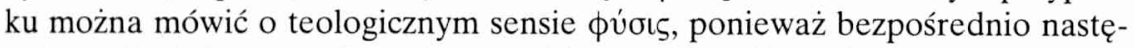
pujące zdanie jest tego dowodem: „A jaka to zaleta dla wody, że spływa w dół? Od Stwórcy dostała tę właściwość"13. Porównując obydwie wypowiedzi, ze względu na ich strukturę merytoryczną, można dostrzec dwie bardzo podobne do siebie frazy. Pierwsza brzmi: „Właściwości palenia udzieliła mu natura”, a druga: „Od Stwórcy dostała tę właściwość”. Dająca się zauważyć równoleg-

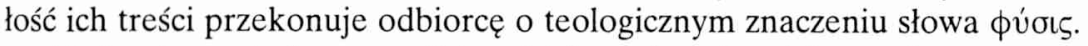

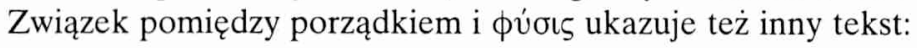

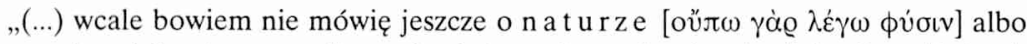
o ruchu nieba, i o porządku gwiazd, i o połączeniu pierwiastków, i o różnicach między zwierzętami, i o stopniach niższych i wyższych mocy niebieskich, i o wszystkim tym, na co dzieli się myśl twórcza, i o zasadach Opatrzności i rządzenia”"14.

Dość zaskakującym wydaje się obecność фúoıs na początku szeregu, w którym wymienione zostały różne obszary świata stworzonego, a nawet

12 Oratio 37, 16, SCh 318, 304, w. 8, tłum. J.M. Szymusiak, Grzegorz Teolog. U źródet chrześcijańskiej myśli IV wieku, Poznań 1965, 375.

13 Oratio 37, 16, SCh 318, 304, w. 8-9, Szymusiak s. 375.

14 Oratio 32, 27, SCh 318, 144, w. 29, Mowy, s. 379. 
obejmujące sferę Opatrzności, ze zwróceniem uwagi na panujący w nich porządek i hierarchię. Czy zatem odnosi się to słowo do świata stworzonego jako całości czy też zwraca uwagę na charakter tego świata, czyli sposób jego bytowania? Wydaje się jednak, że фúøı jest słowem, które oznacza uniwersalnie pojęty porządek w otaczającej rzeczywistości, a nawet wykraczający poza nią. Na taką interpretację wskazują wymienione w dalszej kolejności różne układy uporządkowania przykładowo wymienionych przez Grzegorza kategorii bytów. Zatem фúoıs to szczególny rodzaj uporządkowania, który zawiera w sobie daną przez Stwórcę moc porządkującą.

Uporządkowanie poszczególnych obszarów otaczającej rzeczywistości oraz wzajemne harmonijne między nimi powiązanie stało się porównawczym odniesieniem dla wytworów rąk ludzkich. Kapadocczyk uległ zachwytowi nad pięknością ówczesnej architektury, podziwiając malowidła, „które w niczym nie

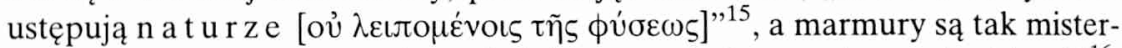

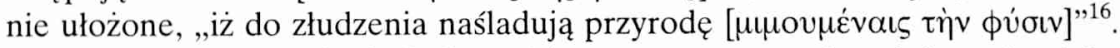
Występujące w tych zdaniach słowo фúoı oznacza otaczający świat pojęty jako całość, a ich szerszy kontekst uzupełnia to znaczenie o myśl, że świat odznacza się pięknością, doskonałością, uporządkowaną harmonią kształtów, a więc

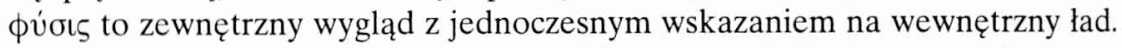

Mimo że Grzegorz z wielkim szacunkiem wypowiada się o otaczającym go świecie materialnym - bez wątpienia ze względu na jego boskie pochodzenie jest jednocześnie świadomy ograniczoności świata jako bytu przygodnego. Dlatego przypomniał o tym słuchaczom, objaśniając, by do rzeczy niebieskich

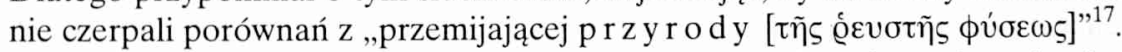

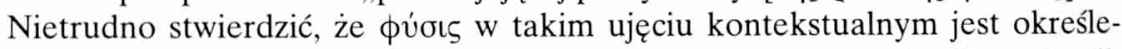
niem całej rzeczywistości stworzonej, zwanej inaczej przyrodą. Przymiotnik

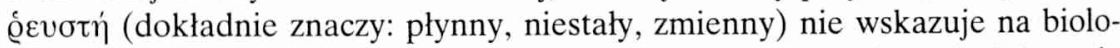
giczne zmiany zachodzące w przyrodzie, czyli np. regularnie zmieniające się pory roku, stale odnawiającą się przyrodę, ale raczej należy rozumieć go w sensie metafizycznym, tzn. informuje on odbiorcę o przygodności całego stworzenia, jego kruchości, przemijalności i ostatecznym końcu.

Ten sam zwrot Grzegorz powtarza w innym kontekście swego nauczania, gdy mówiąc o Bogu, który jest zawsze, objaśnia, że wszystko, co było i będzie,

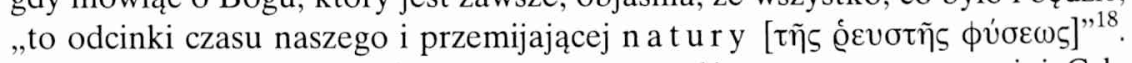
Zwrot ten i w tym przypadku ma tę samą wartość semantyczną, co wyżej. Cały jednak kontekst tej wypowiedzi został wzbogacony o wartość czasu. Biskup konstantynopolitański wymienił tu bowiem dwie kategorie metafizyczne, jaki-

${ }^{15}$ Oratio 18,39 , PG 35,1037 A, Szymusiak s. 342.

16 Oratio 33,7 , SCh 318, 172, w. 12, Mowy, s. 387.

17 Oratio 31,10 , SCh 250, 294, w. 11, Mowy, s. 349.

18 Oratio 38,7 , SCh 358,114 , w. 3, Mowy, s. 418. Ten zwrot pojawia się w powtórzonym przez Grzegorza fragmencie Mowy 45, 3, PG 36, 625C, Mowy, s. 352. 
mi są czas i przestrzeń, określając tę drugą słowem фúoıs. Czy zatem stanowi ono synonim słowa „przestrzeń” czy też wyraża coś innego? Rozwiązanie tej wątpliwości podaje bezpośrednio następująca wypowiedź:

„Albowiem [Bóg] całe bytowanie skupił w sobie i posiada je bez początku i bez końca, jak jakieś niezmierzone i nieograniczone morze bytu, przekraczające wszel-

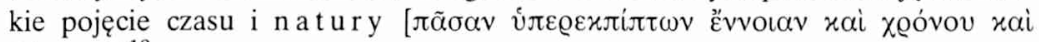

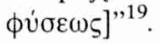

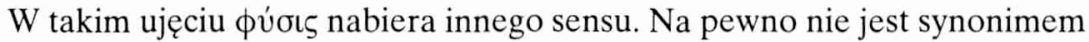
słowa „przestrzeń”, ale raczej kategorią tę przestrzeń porządkującą. Wynika-

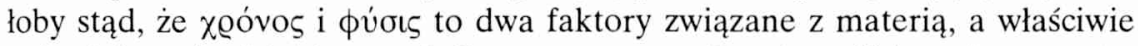
pojawiające się dzięki materii. Są one wyznacznikami swoiście pojętego uporządkowania wartościującego wszelki byt.

W podobnym aspekcie фúøıৎ użyte jest w stwierdzeniu, które odnosi się do Boga, informujące, że ,jest On ponad wszelki byt i ponad naturę [xoi đò

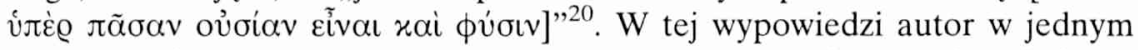
szeregu umieścił dwa terminy, które, począwszy od najstarszych świadectw literatury greckiej, odgrywały ważną rolę we wszelkiej refleksji nad rzeczywis-

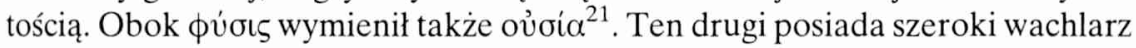
znaczeń, jednak najczęściej oznacza ,istotę”, „byt”, czyli wskazuje na istnienie, a także na jego jakość ${ }^{22}$. W związku z tym powstaje pytanie: czy te dwa terminy można uważać za synonimy? Innymi słowy, czy Grzegorz używając oủoí

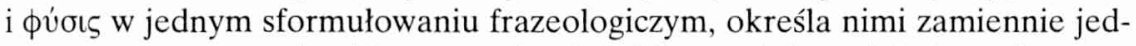
ną i tę samą rzeczywistość czy raczej należy kierować się wyżej sformułowanymi wnioskami analiz pola semantycznego фúøıs? Wydaje się, że na podstawie dokonanych wyżej analiz należy stwierdzić, iż słowo $\phi \dot{\sigma} \sigma \varsigma$ oznacza wprawdzie świat materialny, jednak pojmowane jako uporządkowane obszary bytu, wykazujące wewnętrzną dynamikę i harmonię, w których widoczny jest zamysł Boga jako Stwórcy. Toteż obecność obok siebie oủoi $\alpha$ i фúøıৎ należy potraktować jako dwa różne określenia odnoszące się do tej samej rzeczywistości, z których pierwsze wskazuje na istnienie bytu materialnego, a drugie na wewnętrzny ład, doskonałość i porządek ten byt cechujące.

19 Oratio 38, 7, SCh 358, 114-116, w. 8, Mowy, s. 418. Również ta wypowiedź została powtórzona w Mowie 45, 3, PG 36, 625C, Mowy, s. 352.

${ }^{20}$ Oratio 29, 14, SCh 250, 206, w. 19, Mowy, s. 321.

${ }^{21}$ Na temat stosowania słowa ov̉oi $\alpha$ w mowach Grzegorza z Nazjanzu zob.: N. Widok, Vocis ovoia significationes in Gregorii Nazianzeni orationibus, w: tenże (red.), Veritatem desiderat anima. Studia patrystyczne z okazji 110 rocznicy urodzin Bertholda Altanera (1885-1964), Opole 1995, 189-226.

22 Cenną monografię przedstawiającą funkcjonowanie słowa ov̉oi $\alpha$ w literaturze antycznej i patrystycznej napisał G.Ch. Stead, Divine Substance, Oxford 1977. 
Na zakończenie należy zauważyć, że we wszystkich wyżej przytoczonych tekstach słowo фúoıৎ odnosi się do świata materialnego jako rzeczywistości stworzonej, rozumianej jako całość. W większości przypadków konteksty, w których użyto фúøıs, wyraźnie wskazują na boskie pochodzenie tego świata. Można zatem mówić o teologicznym wymiarze tego słowa. Szerszy kontekst poszczególnych zagadnień rozważanych przez Kapadocczyka wskazuje w sposób jasny na znaczenie, które sygnalizowane jest użyciem фúøıs. Często słowo to wyraża sposób zachowania się świata materialnego, ze szczególnym uwzględnieniem tkwiącej w nim dynamicznej mocy. Ponadto фúøıs oznacza ogólnie pojęty porządek i harmonię całej rzeczywistości stworzonej. Na uwydatnienie takiego znaczenia wpłynął związek frazeologiczny фúoıs z takimi rzeczow-

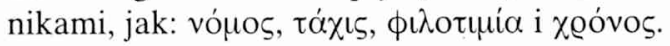

\section{THEOLOGICAL VALUES OF $\Phi Y \Sigma I \Sigma$ IN REFERENCE TO THE NATURAL WORLD IN THE ORATIONS OF GREGORY OF NAZIANZUS}

(Summary)

The article presents the semantic values of púols in reference to the natural

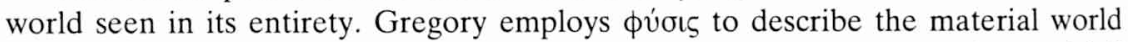
as a divine reality. It means that it is created by God. Therefore it is perfect and full of beauty, which is manifest in its harmony, creative power, dynamism and ontic coherence. 